\title{
Aktivitas Antibakteri Ekstrak Etanol Daun Sukun (Artocarpus altilis) terhadap Bakteri Staphylococcus aureus dan Escherichia coli
}

\section{Antibacterial Activity of Ethanol Extract of Breadfruit Leaf (Artocarpus altilis) Against Staphylococcus aureus and Escherichia coli Bacteria}

\author{
Fuan Maharani Fiana ${ }^{1}$, Naelaz Zukhruf Wakhidatul Kiromah ${ }^{{ }^{*}}$, Ery Purwanti $^{2}$ \\ ${ }^{1}$ Farmasi, Farmasi, STIKES Muhammadiyah Gombong, Jln. Yos Sudarso 461, Gombong, Indonesia \\ ${ }^{2}$ Keperawatan, Keperawatan, STIKES Muhammadiyah Gombong, Jln. Yos Sudarso 461, Gombong, Indonesia \\ *E-mail: naela.zukhruf18@stikesmuhgombong.ac.id
}

Received: 3 Februari 2020; Accepted: 1 Juli 2020; Published: 6 Juli 2020

\begin{abstract}
Abstrak
Diare disebabkan oleh infeksi bakteri terutama Staphylococcus aureus dan Escherichia coli. Daun sukun (Artocarpus altilis) diketahui mengandung senyawa flavonoid, alkaloid, saponin, dan tannin yang dapat dimanfaatkan sebagai antibakteri. Penelitian ini dilakukan untuk mengetahui aktivitas ekstrak etanol daun sukun terhadap bakteri Staphylococcus aureus dan Escherichia coli. Pembuatan ekstrak daun sukun menggunakan metode maserasi dengan pelarut etanol 96\%. Hasil uji tabung dan uji KLT ekstrak daun sukun positif kandungan flavonoid dan tanin yang berpotensi sebagai antibakteri. Uji antibakteri dilakukan menggunakan metode disc diffusion (tes Kirby-Bauer) terhadap bakteri Staphylococcus aureus dan Escherichia coli yang diinkubasi selama 1 x 24 jam. Konsentrasi ekstrak yang diujikan yaitu 10\%, 15\% dan $20 \%$. Kontrol positif menggunakan antibiotik eritromisin dan kontrol negatif menggunakan aquades. Identifikasi kandungan kimia tanaman dilakukan dengan uji tabung dan KLT. Hasil inkubasi ekstrak daun sukun dengan konsentrasi 10\%, 15\% dan 20\% terhadap bakteri Staphylococcus aureus rerata diameter zona hambat berturut-turut yaitu 3,67, 3,50 dan 2,67 mm dengan kontrol positif diameter zona hambat 18,5 $\mathrm{mm}$, kontrol negatif diameter zona hambat $0 \mathrm{~mm}$. Hasil inkubasi ekstrak daun sukun dengan konsentrasi $10 \%$, 15\% dan 20\% terhadap bakteri Escherichia coli rerata diameter zona hambat berturut-turut yaitu 5,33, 3,17 dan 3,33 mm dengan kontrol positif memiliki diameter zona hambat 28,5 mm dan kontrol negatif diameter zona hambat $0 \mathrm{~mm}$. Aktivitas ekstrak etanol daun sukun terhadap bakteri Staphylococcus aureus dan Escherichia coli termasuk dalam kategori lemah.
\end{abstract}

Kata Kunci: Daun sukun, Artocarpus altilis, Antibakteri, Staphylococcus aureus, Escherichia coli.

\begin{abstract}
Diarrhea is caused by bacterial infections, especially Staphylococcus aureus and Escherichia coli. The breadfruit leaves (Artocarpus altilis) are known contain flavonoid compounds, alkaloids, saponins, and tannins which can be used as antibacterial. This research was conducted to determine the ethanol extract of the breadfruit leaves against Staphylococcus aureus and Escherichia coli bacteria. The manufacture of the breadfruit leaf extract was using a maceration method with $96 \%$ ethanol solvent. The result of the tube test and the TLC test was positive, the breadfruit leaf extract containing flavonoids and tannins which have potential as antibacterial. The antibacterial test was carried out using the disc diffusion method (KirbyBauer test) against Staphylococcus aureus and Escherichia coli bacteria incubated for $1 \times 24$ hours. The extract concentrations tested were 10\%, 15\% and 20\%. The positive control was using erythromycin antibiotics and the negative control was using aquades. The identification of the chemical content of plants is done by tube test and the TLC test. The results of incubation of the breadfruit leaf extract with concentrations of 10\%, 15\% and 20\% against Staphylococcus aureus bacteria, the average diameter of inhibitory zones respectively were 3.67, 3.50 and $2.67 \mathrm{~mm}$ with the positive control diameter of inhibition zone was $18.5 \mathrm{~mm}$, the negative control diameter of inhibition zone was $0 \mathrm{~mm}$. The results of incubation of the breadfruit leaf extract with concentrations of 10\%, 15\% and 20\% against Escherichia coli bacteria, the average diameter of inhibitory zones respectively were 5.33, 3.17 and $3.33 \mathrm{~mm}$ with the positive control inhibition zone diameter of $28.5 \mathrm{~mm}$ and the negative control of inhibition zone diameter of $0 \mathrm{~mm}$. The
\end{abstract}


activity of ethanol extract of the breadfruit leaves against the Staphylococcus aureus and Escherichia coli bacteria is categorized weak.

Keywords: The breadfruit leaves, Artocarpus altilis, Antibacterial, Staphylococcus aureus, Escherichia coli.

\section{PENDAHULUAN}

Infeksi bakteri merupakan salah satu penyebab penyakit diare. Bakteri tersebut adalah Staphylococcus aureus dan Escherichia coli (Oroh et al, 2014). Menurut Departemen Kesehatan Republik Indonesia tahun 2016, prevalensi diare yang menyebabkan kematian sebesar 3,04\% (Depkes RI, 2017). Data kasus penyakit diare di Jawa Tengah tahun 2017 sebesar 55,8\% menurun dari tahun sebelumnya pada tahun 2016 sebesar 68,9\% (DinKes Jateng, 2017), walaupun menunjukkan presentase yang menurun namun diare masih menjadi pemicu penyebab kematian. Berdasarkan data Profil Kesehatan Kebumen tahun 2016 telah ditemukan 8 kasus $(2,99 \%)$ diare sebagai penyebab kematian bayi dari 20.44 kelahiran hidup (DinKes Kebumen, 2017). Berdasarkan data diatas penyakit diare akibat dari bakteri harus tetap diwaspadai.

Sekitar $10-20 \%$ penyakit diare yang memerlukan terapi antibiotik sebagai akibat dari infeksi (Purnamasari, 2014). Penggunaan antibiotik yang tidak rasional dapat menyebabkan resistensi bakteri, selain itu penggunaan antibiotik spektrum luas dalam jangka waktu yang lama dapat menyebabkan supra infeksi (Wijaya, 2010).

Tanaman dapat menjadi salah satu alternatif pengobatan dalam mengurangi resistensi terhadap antibiotik (Pandey and Mishra, 2010). Tanaman yang dapat dimanfaatkan sebagai obat salah satunya adalah tanaman sukun (Artocarpus altilis).

Daun sukun secara umum dikalangan masyarakat dimanfaatkan sebagai obat herbal. Tanaman daun sukun memiliki kandungan alkaloid, flavonoid, tanin dan saponin (Rumouw, 2017). Kandungan senyawa tanin dan flavonoid mempunyai aktivitas sebagai antiseptik dan antibakteri (Sa, 2016).

Penelitian Djamil (2017) menunjukkan bahwa ekstrak etanol daun sukun dengan konsentrasi 30, 40, 50, 60\% dapat menghambat pertumbuhan Staphylococcus aureus dengan diameter berturut-turut 14,5 $\mathrm{mm}, 18,1 \mathrm{~mm}, 22 \mathrm{~mm}$, dan $27 \mathrm{~mm}$ (Djamil, 2017). Penelitian Retnaningsih (2016) ekstrak etanol daun sukun menghambat pertumbuhan bakteri Escherichia coli pada konsentrasi $100 \%$ sebesar $11,3 \mathrm{~mm}$, sedangkan terhadap bakteri Shigella dysenteriae pada konsentrasi $80 \%$ sebesar $6,39 \mathrm{~mm}$ (Retnaningsih, 2016). Ekstrak etanol daun sukun pada konsentrasi 10, 15, dan $20 \%$ mampu menghambat pertumbuhan bakteri Staphylococcus epidermis yang merupakan bakteri gram positif (Wulaisfan and Hasnawati, 2017).

Gombong merupakan wilayah yang termasuk dalam Kabupaten Kebumen, di wilayah Kabupaten Kebumen berdasarkan data tercatat tanaman sukun yang menghasilkan pohon sukun (Artocarpus altilis) sebanyak 3.378 (Badan Pusat Statistik, 2018). Berdasarkan uraian diatas maka dilakukan penelitian uji ekstrak etanol daun sukun yang tumbuh di wilayah Gombong terhadap bakteri Staphylococcus aureus dan Escherichia coli dengan tujuan untuk mengetahui aktivitas ekstrak etanol daun sukun (Artocarpus altilis) terhadap bakteri Staphylococcus aureus dan Escherichia coli.

\section{METODE PENELITIAN Bentuk Penelitian}

Penelitian ini merupakan suatu penelitian eksperimental yang dilaksanakan di Laboratorium Fakultas Farmasi STIKES Muhammadiyah Gombong pada bulan AprilMei 2019 untuk pembuatan ekstrak kental daun sukun Artocarpus altilis). Uji Antibakteri dilakukan di Laboratorium Mikrobiologi Fakultas Farmasi Universitas Ahmad Dahlan pada bulan Mei-Juli 2019.

\section{Alat dan Bahan}

Alat yang digunakan dalam penelitian ini adalah gelas-gelas kimia (Pyrex), blender 
(Maspion), timbangan analitik, oven, autoklaf, inkubator, rotary evaporator, waterbath, chamber, UV detektor, jarum ose, kapas steril, cawan petri, jangka sorong, pinset, laminar air flow (LAF).

Bahan yang digunakan dalam penelitian ini adalah daun sukun (Artocarpus altilis) yang berasal dari wilayah Gombong. Etanol 96\%, serbuk magnesium, $\mathrm{HCl}$ pekat, larutan $\mathrm{FeCl} 310 \%, \mathrm{HCl} 2 \mathrm{~N}$, pereaksi Mayer, pereaksi Dragendorff, aquadest, silika GF 254, n-butanol, asam asetat glasial, ammonia pekat, etil asetat, n-heksan, reagen semprot $\mathrm{FeCl} 3$. Larutan kuersetin sebagai pembanding senyawa flavonoid dan larutan asam tanat sebagai pembanding tanin. Bahan untuk uji antibakteri yaitu NA (Nutrient Agar), $\mathrm{NaCl}$ $0,9 \%$, antibiotik erythromycin 500 MG.

\section{Determinasi Tanaman}

Determinasi dilakukan untuk mengetahui kebenaran dari tanaman apakah bahan uji penelitian yang akan digunakan pada penelitian ini benar merupakan daun sukun (Artocarpus altilis).

\section{Pembuatan Simplisia Daun Sukun (Artocarpus altilis)}

Daun sukun (Artocarpus altilis) diperoleh dari daerah Gombong. Daun sukun yang sudah dikumpulkan dibersihkan dengan air yang mengalir kemudian dipotong-potong dan dikeringkan di suhu ruang. Daun sukun (Artocarpus altilis) yang sudah kering kemudian dihaluskan dengan menggunakan blender samapai menjadi serbuk halus.

\section{Ekstraksi Dengan Maserasi}

Menimbang serbuk daun (Artocarpus altilis) sebanyak 250 gram, dimasukan ke dalam wadah, ditambahkan etanol 96\% 1,5 L, diaduk hingga tercampur, ditutup dengan alumunium foil dan disimpan selama 3 hari (terhindar dari cahaya matahari). Selama perendaman setiap hari diaduk selama 15 menit, setelah 3 hari, disaring menggunakan kertas saring untuk memisahkan filtrat hasil maserasi dari serbuk daun sukun (Artocarpus altilis) kemudian diuapkan dengan rotary vacuum evaporator pada temperatur $40^{\circ} \mathrm{C}$ (Bempa et al, 2016). Rendemen ekstrak yang didapatkan kemudian dihitung dengan menggunakan rumus:

$$
\text { Rendemen }=\frac{\text { Bobot ekstrak }}{\text { Bobot simplisia }} \times 100 \%
$$

\section{Skrining Fitokimia Daun Sukun Uji Tabung \\ Uji Flavonoid}

Ekstrak daun sukun dipanaskan selama 5 menit kemudian ditambahkan dengan beberapa tetes $\mathrm{HCl}$ pekat dan serbuk $\mathrm{Mg}$. Warna merah tua yang muncul menunjukkan positif flavonoid (Djamil, 2017).

Uji Tanin

Sebanyak $1 \mathrm{~mL}$ larutan ekstrak uji direaksikan dengan larutan besi (III) klorida $10 \%$, perubahan warna biru tua, biru kehitaman atau hitam kehijauan menunjukkan adanya polifenol dan tanin (Jones and A.D.Kinghorn, 2006).

Uji Alkaloid

Ekstrak atau sampel dilarutkan dengan 5 $\mathrm{mL} \mathrm{HCl} 2 \mathrm{~N}$. Larutan yang didapatkan kemudian dibagi ke dalam 3 tabung reaksi yang berbeda. Tabung pertama ditambahkan dengan $\mathrm{HCl} 2 \mathrm{~N}$ berfungsi sebagai blanko. Tabung kedua ditambahkan perekasi Dragendorff sebanyak 3 tetes dan tabung ketiga ditambahkan pereaksi Mayer sebanyak 3 tetes. Terbentuknya endapan jingga pada tabung kedua dan endapan putih hingga kekuningan pada tabung ketiga menunjukkan adanya alkaloid (Jones and A.D.Kinghorn, 2006).

Uji Saponin

Ekstrak uji dimasukkan ke dalam tabung reaksi, ditambahkan dengan $10 \mathrm{~mL}$ air panas, kemudian didinginkan dan dikocok kuat-kuat selama 10 detik. Terbentuk buih yang stabil selama tidak kurang dari 10 menit setinggi 1$10 \mathrm{~cm}$ pada penambahan $\mathrm{HCl} 2 \mathrm{~N}$, buih tidak hilang (DepKes RI, 1995).

\section{KLT (Kromatografi Lapis Tipis)}

Identifikasi menggunakan KLT dilakukan untuk mengetahui apakah kandungan daun sukun (Artocarpus altilis) mengandung flavonoid dan tanin yang mempunyai aktivitas sebagai antibakteri. Nilai Rf uji KLT dapat dihitung 
menggunakan rumus: Nilai Rf dapat dihitung dengan rumus:

$\mathrm{Rf}=$ Jarak bercak dari tempat penotolan Jarak elusi

\section{Uji Flavonoid}

Silika gel G 60 F 254 dielusi dengan eluen n-butanol:asam asetat glacial:air (8:1: 1). Kuarsetin digunakan sebagai pembanding flavonoid. Kromatogram dilakukan dengan pendeteksi uap ammonia pekat. Terbentuknya warna kuning menunjukkan adanya kandungan flavonoid (Robinson, 1995).

Uji Tanin

Silika gel G 60 F 254 dielusi dengan eluen etil asetat:n-heksan $(2: 8)$. Asam tanat digunakan sebagai pembanding tanin. Hasil positif ditandai dengan adanya bercak abuabu pada sinar tampak (Saifudin, 2014).

\section{Uji Antibakteri}

Sterilisasi Alat Dan Bahan

Alat-alat gelas disterilkan dalam oven dengan suhu $170^{\circ} \mathrm{C}$ selama \pm 2 jam, jarum ose dan pinset dibakar dengan pembakar diatas api langsung dan media disterilkan menggunakan autoklaf pada suhu $121^{\circ} \mathrm{C}$ selama 15 menit (Muljono et al, 2016).

Pembuatan Media NA (Nutrient Agar)

Sebanyak 23-gram media NA serbuk dilarutkan ke dalam 1 liter aquades ke dalam erlenmeyer kemudian dihomogenkan. Tutup Erlenmeyer dengan alumunium foil dan disterilisasi dalam autoclave dengan suhu $121^{\circ} \mathrm{C}$ dan tekanan 2 atm selama 15 menit (Angelika et al, 2014).

\section{Pembuatan Suspensi Bakteri}

Dua sampai tiga ose bakteri pada media NA (Nutrient Agar) yang sudah diinkubasi diencerkan menggunakan $\mathrm{NaCl} 0,9 \%$ steril sebanyak $10 \mathrm{~mL}$ sampai kekeruhannya setara dengan larutan standar 0,5 Mc Farland (Nuria, 2010).

\section{Uji Ekstrak Daun Sukun Terhadap Bakteri}

Pengujian aktivitas antibakteri ekstrak daun sukun dengan berbagai konsentrasi menggunakan metode disc diffusion (tes Kirby Bauer). Memanaskan media NA (Nutrient Agar) kemudian sebanyak $20 \mathrm{~mL}$ dimasukkan ke dalam cawan petri, setelah media memadat kemudian menyelupkan kapas lidi steril ke dalam suspense bakteri, dan diusapkan merata di atas media.

Kertas cakram steril yang berukuran 6 mm direndam selama 15 menit ke dalam 10 mL larutan (Pramita, 2013) ekstrak etanol daun sukun yang mengandung konsentrasi $10 \%$, $15 \%$, dan $20 \%$. Kertas cakram yang telah direndam ekstrak ditempatkan diatas permukaan media pada posisi yang diinginkan. Kontrol positif menggunakan antibiotik eritromisin $15 \mu \mathrm{g} / \mathrm{mL}$ dan kontrol negatif menggunakan aquadest. Cawan petri kemudian diinkubasi pada suhu $37^{\circ} \mathrm{C}$ selama 24 jam kemudian diamati zona hambat yang terbentuk yang diinterpresentasikan dengan melihat daerah bening sekitar cakram yang menunjukkan tidak adanya pertumbuhan bakteri (Pramita, 2013).

\section{Analisa Data}

Pengukuran dimeter zona seperti yang ditunjukkan pada Gambar 1 dapat dihitung dengan rumus $=$

$$
\frac{\left(\mathrm{D}_{\mathrm{V}}-\mathrm{D}_{\mathrm{C}}\right)+\left(\mathrm{D}_{\mathrm{H}}-\mathrm{D}_{\mathrm{C}}\right)}{2}
$$

Keterangan:

$\mathrm{D}_{\mathrm{V}}$ : Diameter Vertikal

$\mathrm{D}_{\mathrm{H}}$ : Diameter Horizontal

$\mathrm{D}_{\mathrm{C}}$ : Diameter Cakram

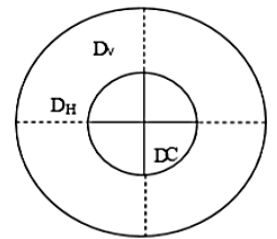

\section{Gambar 1. Pengukuran diameter zona hambat}

Daya antibakteri terbagi menjadi 4 kategori (Davis and Stout, 1971) seperti yang ditunjukkan Tabel 1.

Tabel 1. Kriteria Daya Antibakteri (Davis \& Stout,

\begin{tabular}{cc}
\multicolumn{2}{c}{ 1971) } \\
\hline Kategori Daya & Diameter \\
Hambat & Zona Hambat \\
\hline Lemah & $<5 \mathrm{~mm}$ \\
Sedang & $5-10 \mathrm{~mm}$ \\
Kuat & $10-20 \mathrm{~mm}$ \\
Sangat Kuat & $>20 \mathrm{~mm}$ \\
\hline
\end{tabular}



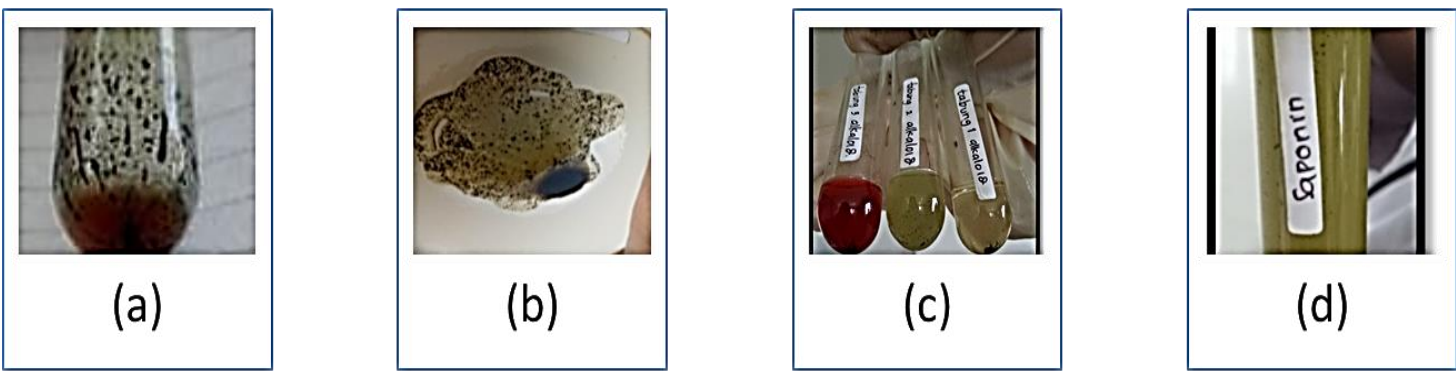

Gambar 2. Skrining Fitokimia Uji Tabung Ekstrak Etanol Daun Sukun

Tabel 2. Skrining Fitokimia Uji Tabung Ekstrak Etanol Daun Sukun

\begin{tabular}{ccccc}
\hline Uji Senyawa & Pereaksi & \multicolumn{2}{c}{ Hasil Uji Senyawa } & Ket \\
\cline { 3 - 4 } & & Positif & Hasil & \\
\hline Flavonoid & $\mathrm{Mg} \mathrm{Serbuk}_{\text {Terah tua }}$ & Merah tua & + \\
Tannin & $\mathrm{FeCl}_{3}$ & Hijau kehitaman & Hijau kehitaman & + \\
Alkaloid & Mayer & Endapan jingga & Endapan hitam & - \\
& Dragendrof & Endapan putih & Endapan hitam & - \\
Saponin & $\mathrm{HCl}$ pekat & Terdapat busa & Tidak berbusa & - \\
\hline
\end{tabular}

\section{HASIL DAN PEMBAHASAN}

Berdasarkan hasil determinasi tanaman, sampel yang dilakukan di Laboratorium Biologi Universitas Ahmad Dahlan Yogyakarta. Sampel yang diambil adalah daun sukun (Artocarpus altilis).

Hasil dari maserasi daun sukun (Artocarpus altilis) dengan etanol 96\% didapatkan ekstrak kental berwarna hijau pekat dengan berat 75,27 gram dari 950 gram serbuk daun sukun (Artocarpus altilis) dengan nilai rendemen sebesar 7,9\%.

Skrining fitokimia pada uji tabung dilakukan untuk menguji ada tidaknya golongan senyawa yang berpotensi sebagai antibakteri yaitu flavonoid, tanin, alkaloid, dan saponin. Berdasarkan hasil dari skrining fitokimia dapat diketahui bahwa ekstrak etanol daun sukun (Artocarpus altilis) positif memiliki kandungan metabolit sekunder flavonoid, tanin dan negatif untuk senyawa metabolit alkaloid dan saponin seperti yang ditunjukkan pada Gambar 2 dan Tabel 2.

Hasil positif flavonoid ditandai dengan timbulnya warna merah tua (Djamil, 2017), dan hasil positif tanin ditandai dengan timbulnya warna hijau kehitaman (Jones and A.D.Kinghorn, 2006). Hasil negatif pada uji alkaloid dikarenakan tidak adanya warna endapan jingga pada saat direaksikan dengan pereaksi Mayer dan tidak adanya endapan putih saat direaksikan dengan pereaksi Dragendrof (Jones and A.D.Kinghorn, 2006) yang timbul ketika direaksi dengan pereaksi Mayer dan Dragendrof hanya timbul warna endapan hitam. Negatif saponin ditandai dengan tidak adanya busa yang muncul setinggi $1-10 \mathrm{~cm}$ dan pada penambahan $\mathrm{HCl}$ 2N, buih menghilang (DepKes RI, 1995).

Berdasarkan uji KLT diketahui ekstrak etanol daun sukun (Artocarpus altilis) positif memiliki kandungan flavonoid dan tanin, seperti yang ditunjukkan pada Tabel 3. Hasil identifikasi flavonoid diketahui pada silica gel setelah pemberian reagen semprot ammonia pekat terdapat satu bercak berwarna kuning dengn nilai Rf 0,93 pada daun sukun (Artocarpus altilis) dan $\mathrm{Rf} 0,90$ pada pembanding kuarsetin. Diketahui nilai $\mathrm{Rf}$ 0,93 merupakan senyawa flavonoid yang 

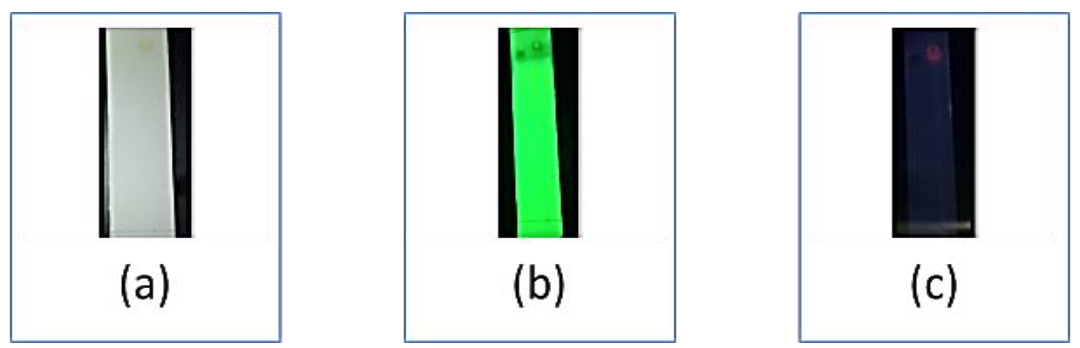

Gambar 3. Hasil Uji KLT Senyawa Flavonoid:

(a) KLT pada sinar tampak, (b) UV $254 \mathrm{~nm}$, (c) UV $366 \mathrm{~nm}$
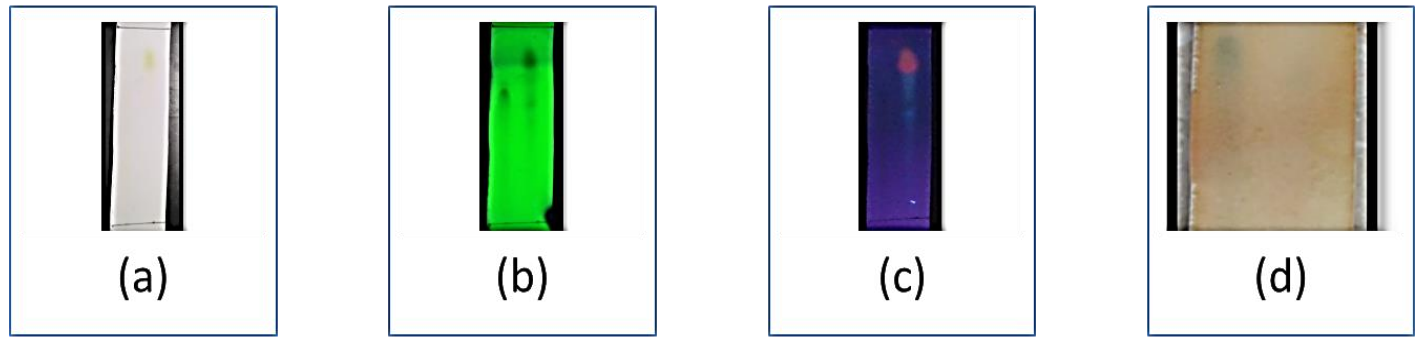

Gambar 4. Hasil Uji KLT senyawa tanin: (a) KLT pada sinar tampak, (b) sinar UV 254 nm, (c) Sinar UV $366 \mathrm{~nm}$, (d) setelah disemprot $\mathrm{FeCl}_{3}$

Tabel 3 Skrining Fitokimia Uji KLT Ekstrak Etanol Daun Sukun

\begin{tabular}{|c|c|c|c|c|c|c|}
\hline \multicolumn{2}{|c|}{ Identifikasi senyawa } & Eluen & $\mathrm{Rf}$ & $\begin{array}{l}\text { Reagen } \\
\text { Semprot }\end{array}$ & Bercak & Ket \\
\hline \multirow[t]{2}{*}{ Flavonoid } & $\begin{array}{l}\text { Ekstrak etanol } \\
\text { daun sukun }\end{array}$ & $\begin{array}{c}\text { n-butanol : } \\
\text { asam asetat } \\
\text { glasial : air } \\
(8: 1: 1) .\end{array}$ & 0,93 & $\begin{array}{c}\text { Ammonia } \\
\text { pekat }\end{array}$ & Kuning & + \\
\hline & $\begin{array}{c}\text { Kuarsetin } \\
\text { (pembanding) }\end{array}$ & $\begin{array}{c}\text { n-butanol : } \\
\text { asam asetat } \\
\text { glasial : air } \\
(8: 1: 1) .\end{array}$ & 0,90 & $\begin{array}{c}\text { Ammonia } \\
\text { pekat }\end{array}$ & Kuning & + \\
\hline \multirow[t]{3}{*}{ Tannin } & $\begin{array}{c}\text { Ekstrak etanol } \\
\text { daun sukun }\end{array}$ & $\begin{array}{l}\text { etil asetat : n- } \\
\text { heksan }(2: 8)\end{array}$ & 0,63 & $\mathrm{FeCl}_{3}$ & Abu-abu & + \\
\hline & & & 0,81 & & Coklat & - \\
\hline & $\begin{array}{c}\text { Asam tanat } \\
\text { (pembanding) }\end{array}$ & $\begin{array}{l}\text { etil asetat : n- } \\
\text { heksan }(2: 8)\end{array}$ & 0,66 & $\mathrm{FeCl}_{3}$ & Abu-abu & + \\
\hline
\end{tabular}

ditandai dengan bercak berwarna kuning menunjukkan adanya kandungan flavonoid (Robinson, 1995). Hal ini didukung pada penelitian yang dilakukan Nuria et al (2009) senyawa flavonoid menghasilkan bercak warna kuning pada nilai Rf 0,98 (Nuria et al, 2009) seperti yang ditunjukkan pada Gambar 3.

Uji KLT ekstrak etanol daun sukun (Artocarpus altilis) untuk identifikasi tanin dilakukan pada silica gel setelah pemberian reagen semprot $\mathrm{FeCl}_{3} 10 \%$ terdapat 2 bercak pada ekstrak etanol daun sukun dengan nilai Rf 0,625 dengan bercak berwarna abu-abu dan $\mathrm{Rf}$ 0,81 dengan bercak warna coklat dan Rf pembanding asam tanat 0,66 dengan bercak berwarna abu-abu. Diketahui nilai Rf 0,625 merupakan senyawa tanin ditandai adanya bercak warna abu-abu (Saifudin, 2014). Hal ini didukung pada penelitian yang 

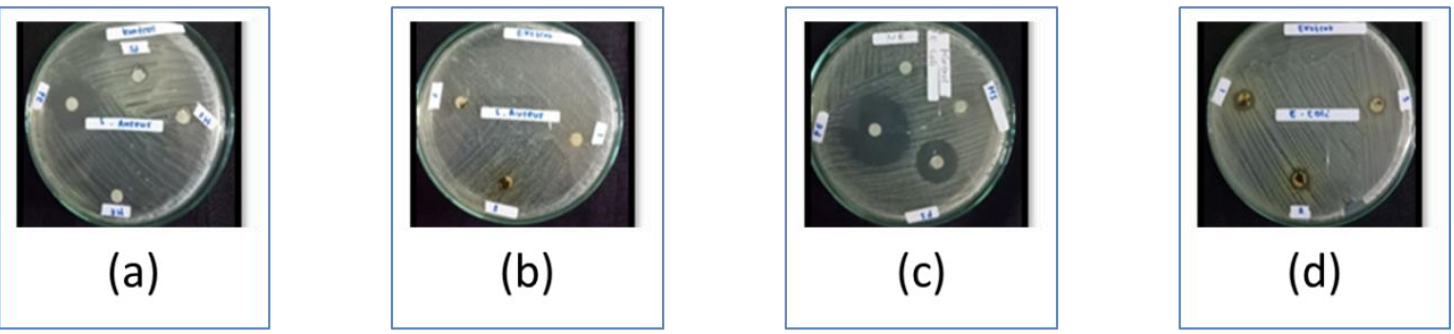

Gambar 5. Uji Antibakteri: bakteri Staphylococcus aureus (a) Uji kontrol positif (PE) dan negatif (NE), (b) uji ekstrak daun sukun 1 (konsentrasi 10\%, 2 15\%), 3 (20\%). Bakteri Escherichia coli (c) Uji kontrol positif (PE) dan negatif (NE), (b) uji ekstrak daun sukun 1 (konsentrasi 10\%, 2 (15\%), 3 (20\%), setelah diinkubasi selama 24 jam dengan suhu $37^{\circ} \mathrm{C}$

Tabel 4. Hasil pengukuran diameter zona hambat

\begin{tabular}{ccc}
\hline \multirow{2}{*}{ Sampel Uji } & \multicolumn{2}{c}{ Rata-Rata Diameter Zona Hambat (mm) \pm SD } \\
\cline { 2 - 3 } & Staphylococcus aureus & Escherichia coli \\
\hline Kontrol positif & $18,5 \pm 5,89$ & $28,5 \pm 3,46$ \\
Kontrol negatif & $0 \pm 0$ & $0 \pm 0$ \\
Konsentrasi ekstrak 10\% & $3,67 \pm 3,75$ & $5,33 \pm 0,58$ \\
Konsentrasi ekstrak 15\% & $3,50 \pm 4,09$ & $3,17 \pm 0,70$ \\
Konsentrasi ekstrak 20\% & $2,67 \pm 2,31$ & $3,33 \pm 2,52$ \\
\hline
\end{tabular}

dilakukan Qolbi dan Yuliani (2018) bahwa senyawa tanin menimbulkan warna abu-abu pada nilai Rf 0,32 (Qolbi and Yuliani, 2018) seperti yang ditunjukkan pada Gambar 4.

Penelitian ini dilakukan dengan membiakkan bakteri Staphylococcus aureus dan Escherichia coli dalam media NA (Nutrient Agar) pada cawan petri dengan meletakkan kertas cakram berukuan $6 \mathrm{~mm}$ yang telah diberi ekstrak daun sukun (Artocarpus altilis) pada konsentrasi 10\%, $15 \%$, dan $20 \%$ dengan 3 kali percobaan. Kontrol negatif menggunakan akuades. Kontrol positif pada uji antibakteri menggunakan antibiotik eritromisin. Eritromisin merupakan antibiotik berspektrum luas, termasuk dalam golongan makrolida. Penggunaannya efektif terhadap bakteri gram positif (Staphylococcus aureus) dan bakteri gram negatif (Escherichia coli). Mekanisme kerjanya, yaitu menghambat sintesis protein dengan cara berikatan pada ribosom subunit $50 \mathrm{~S}$ (Asmat, 2015). Aktivitas antibakteri ekstrak etanol daun sukun (Artocarpus altilis) terhadap bakteri
Staphylococcus aureus dan Escherichia coli dapat dilihat dengan adanya zona hambat yang terbentuk setelah cawan petri diinkubasi selama 24 jam pada suhu $37^{\circ} \mathrm{C}$. Zona hambat yang terbentuk pada uji antibakteri dapat dilihat pada Gambar 5.

Hasil uji antibakteri, kontrol positif berupa antibiotik eritromisin memiliki aktivitas antibakteri terhadap bakteri Staphylococcus aureus dan Escherichia coli, sementara kontrol negatif yaitu aquadest tidak memiliki aktivitas antibakteri. Ekstrak dinyatakan memiliki aktivitas antibakteri ditandai dengan terbentuknya area bening pada sekitar kertas cakram, setelah diinkubasi selama 24 jam pada suhu $37^{\circ} \mathrm{C}$.

Berdasarkan pengamatan yang dilakukan dengan 3 kali pengujian menunjukkan adanya zona hambat yang terbentuk dengan rerata diameter terhadap bakteri Staphylococcus aureus pada konsentrasi ekstrak $10 \%$ rerata diameter zona hambat yang terbentuk adalah $3,67 \mathrm{~mm}$.

Konsentrasi ekstrak $15 \%$ rerata diameter zona hambat yang terbentuk adalah $3,50 \mathrm{~mm}$ 
dan konsentrasi $20 \%$ ekstrak rerata diameter zona hambat yang terbentuk adalah $2,67 \mathrm{~mm}$, sedangkan pada kontrol positif rerata diameter zona hambat yang terbentuk adalah $18,5 \mathrm{~mm}$.

Diameter zona hambat terhadap Escherichia coli pada konsentrasi ekstrak $10 \%$ rerata diameter zona hambat yang terbentuk adalah 5,33 mm. Konsentrasi ekstrak $15 \%$ rerata diameter zona hambat yang terbentuk adalah $3,17 \mathrm{~mm}$ dan konsentrasi $20 \%$ ekstrak rerata diameter zona hambat yang terbentuk adalah $3,33 \mathrm{~mm}$, sedangkan pada kontrol positif rerata diameter zona hambat yang terbentuk adalah 28,5 mm. Pada penelitian ini, diketahui konsentrasi $10 \%$ memiliki diameter zona hambat lebih besar dari pada konsentrasi $15 \%$ dan 20\% terhadap Staphylococcus aureus dan Escherichia coli seperti yang ditunjukkan pada Tabel 4.

Diketahui pada percobaan ke 2 uji ekstrak daun sukun (Artocarpus altilis) terhadap bakteri Staphylococcus aureus didapatkan hasil 0 , hal ini kemungkinan dikarenakan adanya pengaruh dari ekstrak daun sukun yang kurang hati-hati saat memasukkan sampel pada media yang menyebabkan tekontaminasi sehingga menyebabkan komponen kimia yang bersifat antibakteri tidak terbentuk.

Hasil diameter zona hambat ekstrak daun sukun (Artocarpus altilis) terhadap bakteri Staphylococcus aureus pada konsentrasi ekstrak $10 \%, 15 \%$, dan $20 \%$ termasuk dalam kategori daya hambat yang lemah. Sedangkan, hasil uji terhadap bakteri Escherichia coli konsentrasi 10\% termasuk dalam kategori daya hambat sedang karena diameter zona hambat yang terbentuk lebih dari $5 \mathrm{~mm}$, dan untuk konsentrasi ekstrak $15 \%, 20 \%$ termasuk dalam kategori daya hambat yang lemah lemah karena diameter zona hambat yang terbentuk kurang dari 5 mm (Davis and Stout, 1971).

Berbeda dengan penelitian sebelumnya, yang menyimpulkan bahwa hasil antibakteri ekstrak etanol daun sukun (Artocarpus altilis) terhadap bakteri gram positif pada konsentrasi $15 \%$ dan $20 \%$ termasuk dalam kategori daya hambat sedang karena diameter zona hambat yang terbentuk lebih dari $5 \mathrm{~mm}$ (Wulaisfan and Hasnawati, 2017). Penelitian Retnaningsih (2016) juga menyimpulkan bahwa ekstrak etanol daun sukun pada konsentrasi 20\% tidak mampu menghambat bakteri Escherichia coli (Retnaningsih, 2016).

Aktivitas ekstrak etanol daun sukun (Artocarpus altilis) dalam menghambat pertumbuhan bakteri pada penelitian ini lebih aktif dalam menghambat bakteri gram negatif Escherichia coli dibandingkan bakteri gram positif Staphylococcus aureus. Hal ini dikarenakan bakteri Escherichia coli merupakan bakteri negatif sedangkan bakteri Staphylococcus aureus merupakan bakteri gram positif yang kedua jenis bakteri tersebut memiliki dinding sel yang berbeda. Bakteri gram positif pada dinding selnya memiliki lapisan peptidoglikan yang tebal dan kaku, sementara bakteri gram negatif pada dinding selnya memiliki lapisan peptidoglikan yang tebal dan kaku, sementara bakteri gram negatif pada dinding selnya memiliki lapisan peptidoglikan yang tipis sehingga dinding sel pada bakteri gram negatif mudah rusak (Sudarmi et al, 2017).

Perbedaan hasil antibakteri ekstrak daun sukun (Artocarpus altilis) pada bakteri gram positif dengan penelitian sebelumnya dimana konsentrasi $15 \%$ dan $20 \%$ termasuk dalam kategori sedang, sementara pada penelitian ini lemah kemungkinan dikarenakan ekstrak etanol sukun (Artocarpus altilis) pada penelitian ini hanya mengandung senyawa tanin dan flavonoid. Kemampuan suatu ekstrak dalam menghambat pertumbuhan bakteri dapat dipengaruhi oleh konsentrasi ekstrak dan golongan senyawa antimikroba yang dihasilkan oleh ekstrak tersebut (Sudarmi et al, 2017). Senyawa flavonoid berfungsi sebagai antibakteri dengan menyebabkan terjadinya kerusakan permeabilitas dinding sel bakteri, mikrosom, lisosom sebagai hasil interaksi antara 
flavonoid dan DNA (Cushnie and Lamb, 2005). Senyawa tanin sebagai antibakteri yaitu dengan menghambat enzim reverse transkiptase dan DNA topoisomerase sehingga sel bakteri tidak terbentuk (Nuria et al, 2009). Alkaloid serta saponin dapat berfungsi sebagai antibakteri senyawa alkaloid sebagai antibakteri memiliki kemampuan mengganggu komponen penyusun peptidoglikan pada sel bakteri, sehingga lapisan dinding sel tidak terbentuk secara utuh dan menyebabkan kematian sel (Darsana et al, 2012), sementara senyawa saponin bekerja dengan cara memecah atau melisis dinding bakteri (Karlina, 2013).

Berdasarkan uraian di atas, daun sukun (Artocarpus altilis) yang tumbuh di wilayah
Gombong, memiliki aktivitas antibakteri pada konsentrasi ekstrak 10\%, $15 \%$ dan $20 \%$. Namun dalam hal ini belum cukup dikatakan potensial. Potensi aktivitas antibakteri dari suatu ekstrak dinyatakan apabila zona hambat yang terbentuk minimal sebesar $1,4 \mathrm{~cm}$ (Angelica, 2013).

\section{KESIMPULAN}

Ekstrak etanol daun sukun (Artocarpus altilis) mengandung senyawa flavonoid dan tanin. Hal ini ekstrak etanol daun sukun (Artocarpus altilis) dengan konsentrasi 10, 15, dan 20\% terhadap bakteri Staphylococcus dan Escherichia coli berdasarkan rata-rata diameter zona hambat mayoritas termasuk kategori lemah.

\section{Daftar Pustaka}

Angelica, N. 2013. Aktivitas Antibakteri Ekstrak Etanol Daun Dan Kulit Batang Kayu Manis (Cinnamomum burmannii (Nees \& Th. Nees)) Terhadap Escherichia coli Dan Staphylococcus aureus. JIFFK : Jurnal Ilmu Farmasi Dan Farmasi Klinik, 2(2).

Angelika, G. P., Agung, S., \& Pujiyanto, S. 2014. Uji Aktivitas Antibakteri Ekstrak Tumbuhan Euphorbia hirta L. Terhadap Ralstonia solanacearum, Escherichia coli, Dan Staphylococcus aureus Secara In Vitro. Jurnal Biologi, 3(2), 49-58.

Asmat, M. A. Bin. 2015. Uji Sensitivitas Antibiotika Pada Isolat Lapang Staphylococcus aureus. Departemen Ilmu Penyakit Hewan Dan Kesmavet Fakultas Kedokteran Hewan Institut Pertanian Bogor.

Badan Pusat Statistik. 2018. BPS Provinsi Jawa Tengah. Badan Pusat Statistik.

Bempa, S. L. P., Fatimawali, \& Parengkuan, W. G. 2016. Uji Daya Hambat Ekstrak Daun Sukun (Artocarpus altilis) Terhadap Pertumbuhan Bakteri Streptococcus mutans. Pharmacon Jurnal Ilmiah Farmasi, 5(4), 655-656.

Cushnie, T. P. T., \& Lamb, A. J. 2005. Antimicrobial activity of flavonoids. International Journal of Antimicrobial Agents, 26(5), 343-356.

Darsana, I., Besung, I., \& Mahatim, H. 2012. Potensi Daun Binahong (Anredera Cordifolia (Tenore) Steenis) dalam Menghambat Pertumbuhan Bakteri Escherichia coli secara In Vitro. Indonesia Medicus Veterinus, 1(3), 337-351.

Davis, W. W., \& Stout, T. R. 1971. Disc plate method of microbiological antibiotic assay. II. Novel procedure offering improved accuracy. Applied Microbiology, 22(4), 666-670.

Departemen Kesehatan Republik, I. 1995. Farmakope Indonesia. Vol. IV. Jakarta.

Departemen Kesehatan Republik, I. 2017. Profil Kesehatan Indonesia 2016. In Profil Kesehatan Indonesia Tahun 2016.

Dinkes Jateng. 2017. Profil Kesehatan Provinsi Jawa Tengah 2017. Vol. 3511351. Jawa 
Tengah

Dinkes Kebumen. 2017. Profil Kesehatan Kabupaten Kebumen 2016. Kebumen

Djamil, M. I. 2017. Uji Aktivitas Antibakteri Ekstrak Etanol Daun Sukun (Artocarpus altilis) Terhadap Pertumbuhan Staphylococcus aureus Secara In Vitro. Program Studi Kedokteran Hewan Fakultas Kedokteran Universitas Hasanuddin Makassar.

Jones, W. P., \& A.D.Kinghorn. 2006. Extraction of Plant Secondary Metabolites. In: Sarker, S. D., Latif, Z. and Gray, A. I., eds. Natural Products Isolation. 2nd Ed. New Jersey: Humana Press. P.341-342.

Karlina, Y. C. 2013. Aktivitas Antibakteri Ekstrak Herba Krokot (Portulaca oleracea L.) terhadap Staphylococcus aureus dan Escherichia coli. LenteraBio, 2(1), 87-93.

Muljono, P., . F., \& Manampiring, A. E. 2016. Uji aktivitas antibakteri ekstrak daun mayana jantan (Coleus atropurpureus Benth) terhadap pertumbuhan bakteri Streptococcus Sp. dan Pseudomonas Sp. Jurnal E-Biomedik, 4(1), 164-172.

Nuria, M. C. 2010. Antibacterial Activities From Jangkang (Homalocladium platycladum (F. Muell) Bailey) Leaves. Jurnal Ilmu-Ilmu Pertanian, 6(2), 9-15.

Nuria, M. cut, Faizatun, A., \& Sumantri. 2009. Uji Aktivitas Antibakteri Ekstrak Etanol Daun Jarak Pagar (Jatropha Curcas L) Terhadap Bakteri Staphylococcus aureus ATCC 25923, Escherichia coli ATCC 25922, Dan Salmonella typhi ATCC 1408. Jurnal Ilmu-Ilmu Pertanian.

Oroh, S. B., Kandou, F. E. F., Pelealu, J., \& Pandiangan, D. 2014. Uji Daya Hambat Ekstrak Metanol Selaginella delicatula Dan Diplazium dilatatum Terhadap Bakteri Staphylococcus aureus dan Escherichia coli. Jurnal Mikrobiologi, 1(1), 240-247.

Pandey, R., \& Mishra, A. 2010. Antibacterial Activities of Crude Extract of Aloe Barbadensis to Clinically Isolated Bacterial P. Applied Biochemistry and Biotechnology, 160(5), 13561361.

Pramita, F. Y. 2013. Naskah publikasi skripsi formulasi sediaan gel antiseptik ekstrak metanol daun kesum. Program Studi Farmasi Fakultas Kedokteran Universitas Tanjungpura Pontianak.

Purnamasari, N. D. 2014. Evaluasi Terapi Diare Pada Pasien Anak Di Puskesmas Nguter Kecamatan Nguter Kabupaten Sukoharjo Tahun 2012. In Fakultas Farmasi Universitas Muhammadiyah Surakarta. Jakarta: Badan Penelitian dan Pengembangan Kesehatan Departemen Kesehatan RI.

Qolbi, N. and Yuliani, R., 2018. Skrining Aktivitas Antibakteri Ekstrak Etanol 70\% Sepuluh Daun Tanaman Terhadap Klebsiella Pneumoniae. Pharmacon: Jurnal Farmasi Indonesia, 15(1), pp.8-18.

Retnaningsih, A. 2016. Uji Daya Hambat Ekstrak Daun Sukun (Artocarpus altilis) Terhadap Pertumbuhan Bakteri Escherichia coli Dan Shigella dysenteriae. Journal of Chemical Information and Modeling, 2(2), 97-100.

Robinson, J. T. 1995. Kandungan Organik Tanaman Tingkat Tinggi, Edisi VI diterjemahkan oleh Padmawinata, K.

Rumouw, D. 2017. Identifikasi Dan Analisis Kandungan Fitokimia Tumbuhan Alam 
Berkhasiat Obat Yang Dimanfaatkan Masyarakat Sekitar Kawasan Hutan Lindung Sahendaruman. Jurnal LPPM Bidang Sains Dan Teknologi, 4(2).

Sa-Anis. 2016. Formulasi Sediaan Salep Ekstrak Etanol Daun Kirinyuh (Euphatorium odoratum L.) Sebagai Penyembuh Luka Terbuka Pada Kelinci. e-print UMS, 1-15.

Saifudin, A. 2014. Senyawa Alam Metabolit Sekunder (Teori, Konsep, dan Teknik Pemurnian). In Deepublish, Yogyakarta.

Sudarmi, K., Bagus, I., Darmayasa, G., \& Muksin, I. K. 2017. Uji Fitokimia Dan Daya Hambat Ekstrak Daun Juwet (Syzygium cumini) Terhadap Pertumbuhan Escherichia coli Dan Staphylococcus aureus Atcc. (September), 47-51.

Wijaya, Ayu. Ariani. 2010. Diare Pada Pasien Rawat Inap Di Rumah Sakit Umum Daerah Kabupaten Karanganyar Tahun 2009. Fakultas Farmasi Universitas Muhammadiyah Surakarta Surakarta.

Wulaisfan, R. and Hasnawati, H., 2017. Uji Daya Hambat Ekstrak Daun Sukun (Artocarpus Altilis) Terhadap Pertumbuhan Bakteri Staphylococcus Epidermidis. Warta Farmasi, 6(1), pp.90-99. 